\title{
Dietary starch and sugar versus fat and fiber: growth and development of foals
}

\author{
R. M. Hoffman, D. S. Kronfeld, L. A. Lawrence, W. L. Cooper, J. J. Dascanio and P. A. Harris
}

Virginia Tech MARE Center, Middleburg, USA

\begin{abstract}
Summary
Growth and development of foals were examined in terms of body weight and body condition score, wither and hip heights, lengths of body, forearm and cannon bones, girth and circumferences of the physis and fetlocks. The experimental plan included two dietary groups of mares with foals maintained on pasture and supplemented with either a corn and molasses based sweet feed (SS), or a corn oil and fiber supplement (FF). Body weight and body condition scores were similar for both groups from birth until the following March when both declined in the SS group; when later switched to the FF diet, the SS group compensated in weight and condition.
\end{abstract}

keywords: $\quad$ rapidly fermentable carbohydrate, fat, fiber, growth

\begin{abstract}
Stärke und Zucker in der Futterration gegenüber Fett und Rohfaser: Wachstum und Entwicklung der Fohlen
Wachstum und Entwicklung von Fohlen wurde anhand von Körpergewicht und Körperkondition, Widerrist- und Hüfthöhe, Länge des Körpers, Unterarmes und Mittelfußes, Brustumfang sowie Umfang des Radius und Metacarpus überprüft. Der Versuchsplan sah zwei Fütterungsgruppen von Stuten mit ihren Fohlen vor, die auf der Weide gehalten wurden und entweder ein süßes, aus Mais und Melasse bestehendes (SS) oder ein fett- und faserreiches Ergänzungsfutter (FF) erhielten. Körpergewicht und -kondition waren bei beiden Gruppen gleich von der Geburt an bis zum März des folgenden Jahres, als in der SS-Gruppe beide Parameter abfielen. Nach einer späteren Umstellung dieser Gruppe auf FF-Futter wurden diese Veränderungen kompensiert.
\end{abstract}

Schlüsselwörter: leicht verdauliche Kohlenhydrate, Fett, Rohfaser, Wachstum

\section{Introduction}

Rapidly fermentable carbohydrate has been implicated as an etiologic factor in colic, laminitis and developmental orthopedic disease (Sprouse et al. 1987; Clarke et al. 1990; Williams and Pugh 1993). It may become excessive when rapidly growing pastures are supplemented with concentrates rich in starch and sugar. Our objectives were to compare growth and bone development of foals fed pasture and supplements rich in starch and sugar or in fat and fiber.

\section{Materials and methods}

Thoroughbred mares with foals were kept on bluegrass clover pasture at the Virginia Tech Middleburg Agricultural Research and Extension (MARE) Center and supplemented with either a corn and molasses based concentrate high in starch and sugar (SS), or a corn oil and fiber supplement high in fat and fiber (FF). Ad libitum access to a mixed grass legume hay was provided in the winter months, and plain white salt was provided free choice throughout the year. The concentrates (Tab. 1) were isoenergetic and isonitrogenous, with mineral contents balanced to meet or exceed NRC requirements (NRC 1989). Anthelmintic, vaccination, and hoof trimming schedules routine to the Virginia Tech MARE Center were followed (Ley et al. 1992).

The mares and foals were fed in pans on the ground so that both had access to the supplement. The foals were weaned between 5 to 7 months of age and maintained on their respective diets. The supplements were fed in varying amounts with goals of a 1:2 supplement:forage ratio and body condition scores maintained between 5 and 6.

Ten foals per group were studied in 1994 and 1995. Growth rates were measured monthly by body weight, body condition score, wither and hip heights, lengths of body, forearm and cannon bones, girth, and circumferences of the physis and fetlocks. Measurements are further defined as follows: Wither Height the distance from the ground to the highest point of the withers; Hip Height the distance from the ground to the highest point of the croup; Body Length the distance from the point of the shoulder to the point of the buttock; Girth the circumference of the girth behind the elbow and over the highest 
Tab. 1: Nutrient profile of the supplements, as fed ${ }^{a}$, and MARE Center bluegrass clover pasture $(90 \%$ confidence interval), on a dry matter basis.

Zusammensetzung der Supplemente ( ursprüngliche Substanz) und des Weidefutters der Versuchstiere (bezogen auf Trockensubstanz, 90\% Konfidenzintervall)

\begin{tabular}{|l|c|c|l|}
\hline Nutrient & $\begin{array}{l}\text { Starch \& } \\
\text { Sugar (SS) }\end{array}$ & $\begin{array}{l}\text { Fat \& } \\
\text { Fiber (FF) }\end{array}$ & $\begin{array}{l}\text { Pasture } \\
(\mathrm{n}=20)\end{array}$ \\
\hline Dig Energy, MJ/kg & 12.5 & 12.5 & $5.8-19.6$ \\
\hline Crude Protein, \% & 14.6 & 15.3 & $12.5-24.4$ \\
\hline NDF, \% & 12.6 & 34.0 & not analyzed \\
\hline ADF, \% & 7.15 & 22.8 & $24.7-35.5$ \\
\hline Ether Extract, \% & 2.32 & 12.20 & not analyzed \\
\hline Calcium, \% & .93 & .95 & $.26-.65$ \\
\hline Phosphorus, \% & .57 & .56 & $.23-.36$ \\
\hline Iron, mg/kg & 150 & 150 & $89-524$ \\
\hline Zinc, mg/kg & 192 & 192 & $17.7-31.4$ \\
\hline Copper, $\mathrm{mg} / \mathrm{kg}$ & 60 & 60 & $6.1-13.8$ \\
\hline Manganese, mg/kg & 192 & 192 & $34.4-98.6$ \\
\hline Selenium, mg/kg & .6 & .6 & $<.08$ \\
\hline lodine, mg/kg & .6 & .6 & $<.08$ \\
\hline
\end{tabular}

aCalculated from ingredients using NRC tables. the distance from the accessory carpal bone to the proximal sesamoids; Hind Cannon the distance from the point of the hock (calcaneus) to the proximal sesamoids; Physis the circumference of the knee at the metaphysis of the distal radius, just above the accessory carpal bone; Fetlock the circumference of the fetlock at the metaphysis of the distal third metacarpal bone, just above the proximal sesamoids.

\section{Results}

Body weight and body condition scores (Fig. 1) were similar in both groups of 1994 foals from birth until the following March (10 to 12 mo of age) when both declined in the SS group. The SS group remained behind the FF group in weight and condition from March through June, at which point the SS group was switched to the FF diet and examined for compensatory growth. The FF group remained on their diet during this time. Within a month of the dietary change, the SS group began to gain weight, and eventually condition. By October, the two groups were the same in weight and condition.

Wither and hip heights, lengths of body, forearm and cannon bones, girth, and circumferences of the physis and fetlocks were similar for both groups (Fig. 2 and 3). Girth circumference data reflect the changes in weight and condition in both groups, however, overall frame size was not influenced by the loss of weight and condition apparent in the SS group. a

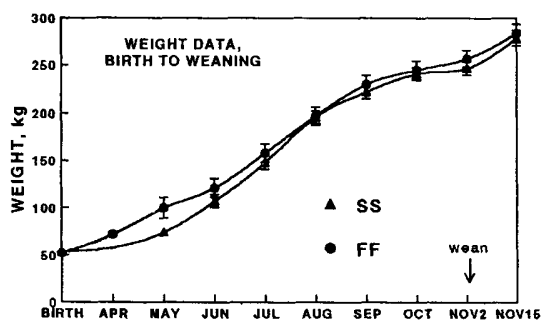

C

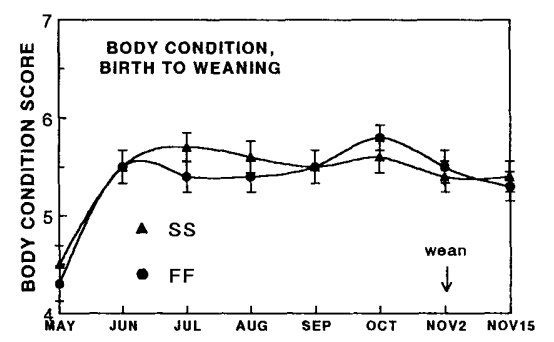

b

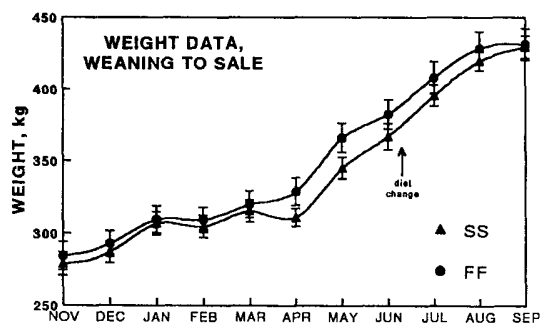

d

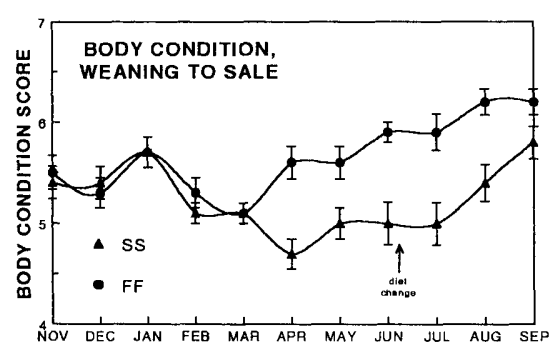

Fig. 1: Monthly body weights (a, b) and body condition scores (c, d) of 1994 Thoroughbred foals from birth to weaning and from weaning to sale.

Monatliche Gewichte ( $\mathrm{a}, \mathrm{b})$ und Konditionspunkte (c, d) bei den 1994 geborenen Vollblutfohlen von der Geburt bis zum Absetzen und vom Absetzen bis zum Verkauf

point of the withers; Forearm the distance from the point of the elbow to the accessory carpal bone; Front Cannon
Shedding of the winter coat occurred approximately 3 to 4 weeks later for the yearlings on the SS diet, as compa- 




C

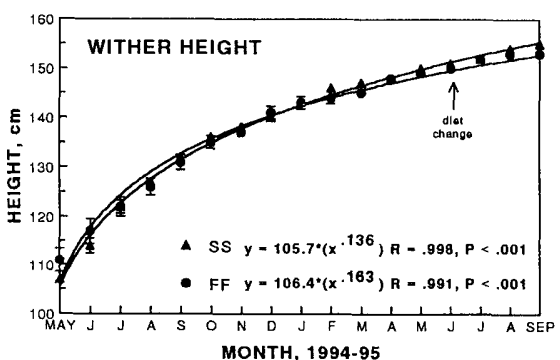

MONTH, 1994-95

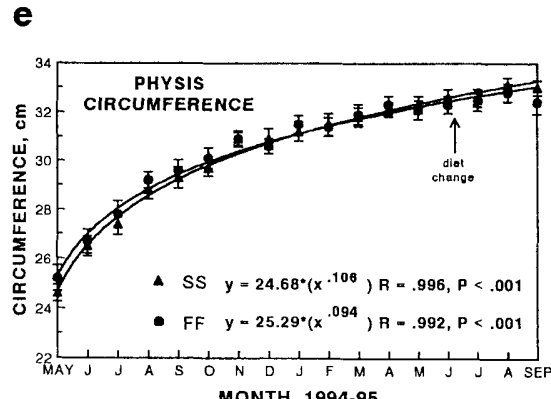

b



d

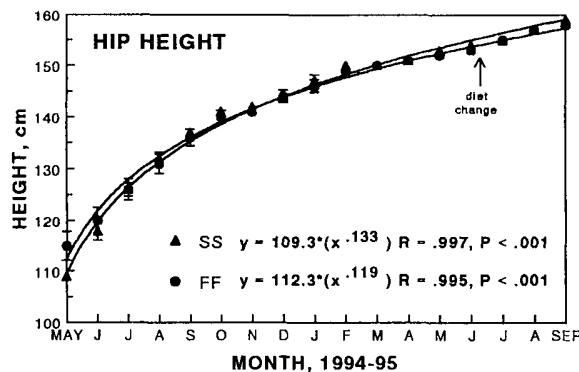

f

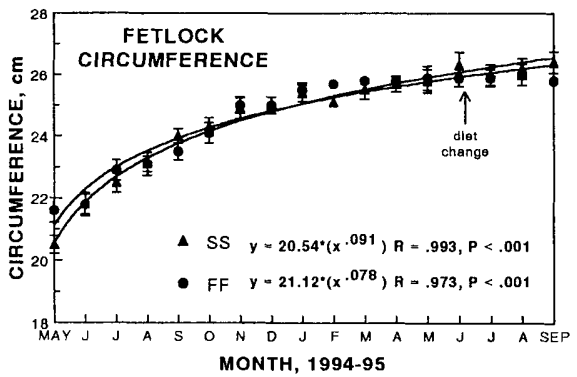

Fig. 2: Girth circumference (a) and growth curves for body length (b), wither and hip heights (c, d), physis and fetlock circumferences (e, f) of 1994 Thoroughbred foals from May 1994 to September 1995 (birth to 16 mo of age).

Brustumfang (a), Wachstum der Körperlänge (b), Widerrist- und Hüfthöhe (c, d), Umfang von Radius (e) und Metacarpus ( $f$ ) der 1994 geborenen Vollblutfohlen von Mai 1994 bis September 1995 (Geburt bis zum 16. Monat)

red to the FF diet. The FF yearlings maintained hair coats superior to those of the SS yearlings throughout the spring and summer months.

\section{Discussion}

The growth rates noted in this study were similar to the weight and frame size data reported by Thompson (1995) and to those reported by Hintz et al. (1979). The rate of weight gain in the present study, compared to data from Ott and Asquith (1986), was lower than their yearling horses given ad libitum access to their concentrate and higher than their horses with restricted access. In another study, higher planes of nutrition increased body weight gains and long bone growth (Thompson et al. 1988).

The loss of weight and condition evident in the SS group (Fig. 1) coincided directly with the appearance of spring pasture growth. Observations during this time indicated that both groups of horses were consuming the young growing pasture in preference to the hay offered. The differences in weight and condition during this time may have been due to a more rapid rate of passage and an excess of rapidly fermentable carbohydrate, occurring when the SS concentrate was consumed in combination with the young forage. We suggest that the FF concentrate afforded some protection against the high sugar and low fiber content of spring pasture.

Previous research at the Virginia Tech MARE Center indicated that supplementation of pasture is necessary to provide adequate amounts of vitamin A, phosphorus, selenium, copper and zinc throughout the year (GreiweCrandell et al. 1995; Hoffman et al. 1995). The present study shows the value of fat and fiber supplementation, especially during rapid pasture growth. 
a

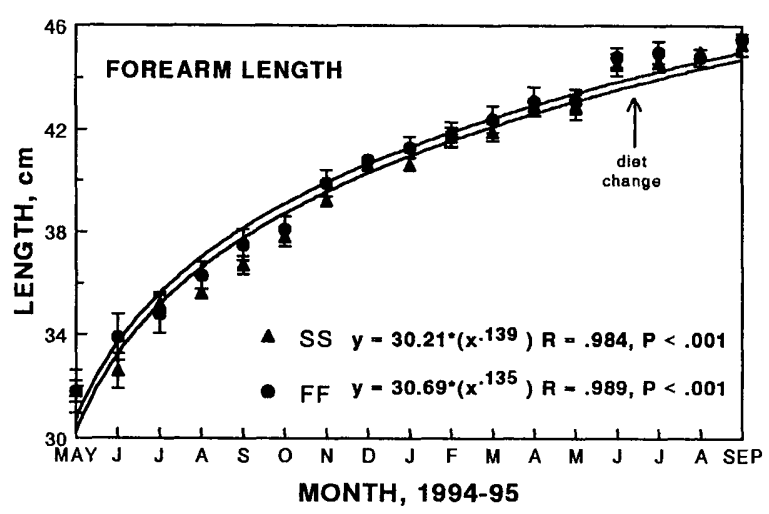

b

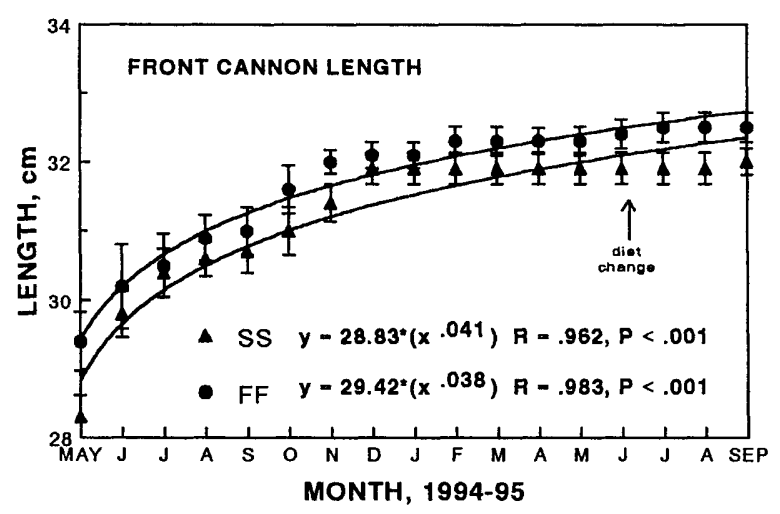

C

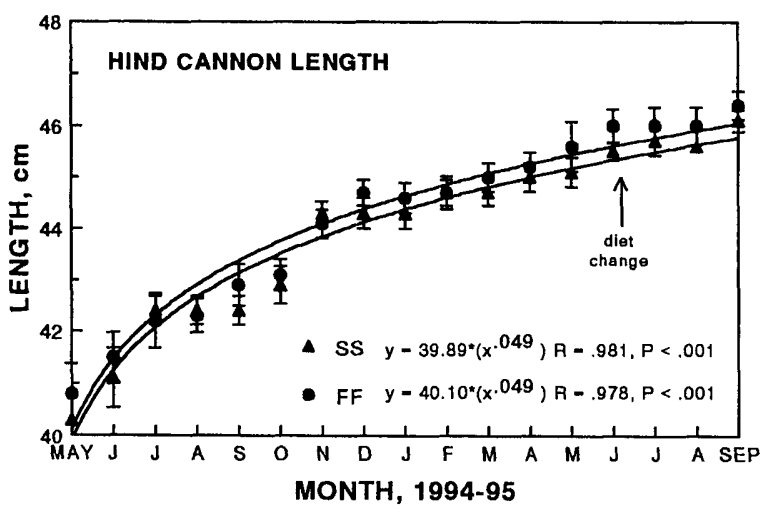

Fig. 3: Growth curves for forearm (a), front and hind cannon lengths (b, c) of 1994 Thoroughbred foals from May 1994 to September 1995 (birth to 16 mo of age).

Wachstumskurve des Unterarmes (a), Länge des vorderen und hinteren Mittelfußes (b, c) der 1994 geborenen Vollblutfohlen von Mai 1994 bis September 1995 (Geburt bis zum 16. Monat)

\section{References}

Clarke, L. L., Roberts, M. C. and Argenzio, R. A. (1990): Feeding and digestive problems in horses. Vet. Clin. N. Amer. Equine Prac. 6, 433-451.

Greiwe-Crandell, K. (1995): Seasonal vitamin A depletion in grazing horses is assessed better by the relative dose response test than by serum retinol concentration. J. Nutr. 22, 2711-2716.

Hintz, H. F., Hintz, R. L. and Van Vleck, L. D. (1979): Growth rate of Thoroughbreds. Effect of age of dam, year and month of birth, and sex of foal. J. Anim. Sci. 48, 480-487.

Hoffman, R. M., Kronfeld, D. S., Holland, J. L. and Greiwe-Crandell, K. M. (1995): Preweaning diet and stall weaning method influences on stress response in foals. J. Anim. Sci. 73, 2922-2930.

Ley, W. B., Bowen, J. M. and Thatcher, C. D. (1992): Equine Preventive Medicine. Virginia Maryland Regional College of Veterinary Medicine, Blacksburg, VA.

NRC (1989): Nutrient Requirements of Horses (5th Ed.). National Academy Press, Washington, DC.

Ott, E. A. and Asquith, R. L. (1986): Influence of level of feeding and nutrient content of the concentrate on growth and development of yearling horses. J. Anim. Sci. 62, 290-299.

Sprouse, R. F., Garner, H. E. and Green, E. M. (1987): Plasma endotoxin levels in horses subjected to carbohydrate induced laminitis. Equine Vet. J. 9, 25-28.

Thompson, K. (1995): Skeletal growth rates of weanling and yearling thoroughbred horses. J. Anim. Sci. 73, 2513-2517.

Thompson, K. N., Jackson, S. G. and Baker, J. P. (1988): The influence of high planes of nutrition on skeletal growth and development of weanling horses. J. Anim. Sci. 66, 2459-2467.

Williams, M. A. and Pugh, D. C. (1993): Developmental orthopedic disease: minimizing the incidence of a poorly understood disorder. Equine Athlete. 15, 859-872.

We appreciate the support of Mr. Paul Mellon, Upperville, VA; the John Lee Pratt Graduate Fellowship Program in Animal Nutrition at Virginia Tech; and the Waltham Centre for Equine Nutrition and Care, Verden, Germany. The technical assistance and encouragement of the staff at the Virginia Tech MARE Center is gratefully acknowledged.

\section{Rhonda M. Hoffman}

Virginia Tech MARE Center 5527 Sullivans Mill Rd. Middleburg, VA 22117-9701 USA 